\title{
Ecosystem Performance Monitoring of Rangelands by Integrating Modeling and Remote Sensing
}

\author{
Bruce K. Wylie, ${ }^{1}$ Stephen P. Boyte, ${ }^{2}$ and Donald J. Major ${ }^{3}$ \\ Authors are ${ }^{1}$ Research Physical Scientist, USGS EROS Center, Sioux Falls, SD 57198, USA; ${ }^{2}$ Senior Scientist, Stinger Ghaffarian Technologies, Inc., \\ contractor to the USGS EROS Center, Sioux Falls, SD 57198, USA; and ${ }^{3}$ Fire and Landscape Ecologist, Bureau of Land Management-Great Basin \\ Restoration Initiative, Boise, ID 83709, USA.
}

\begin{abstract}
Monitoring rangeland ecosystem dynamics, production, and performance is valuable for researchers and land managers. However, ecosystem monitoring studies can be difficult to interpret and apply appropriately if management decisions and disturbances are inseparable from the ecosystem's climate signal. This study separates seasonal weather influences from influences caused by disturbances and management decisions, making interannual time-series analysis more consistent and interpretable. We compared the actual ecosystem performance (AEP) of five rangeland vegetation types in the Owyhee Uplands for $9 \mathrm{yr}$ to their expected ecosystem performance (EEP). Integrated growing season Normalized Difference Vegetation Index data for each of the nine growing seasons served as a proxy for annual AEP. Regression-tree models used long-term site potential, seasonal weather, and land cover data sets to generate annual EEP, an estimate of ecosystem performance incorporating annual weather variations. The difference between AEP and EEP provided a performance measure for each pixel in the study area. Ecosystem performance anomalies occurred when the ecosystem performed significantly better or worse than the model predicted. About 14\% of the Owyhee Uplands showed a trend of significant underperformance or overperformance $(P<0.10)$. Land managers can use results from weather-based rangeland ecosystem performance models to help support adaptive management strategies.
\end{abstract}

\section{Resumen}

El monitoreo del desempeño, producción y dinámica de los ecosistema de pastizal es valioso para investigadores y manejadores de tierras. Sin embargo, los estudios de monitoreo del ecosistema pueden ser difíciles de interpretar y aplicar apropiadamente, si las decisiones de manejo y disturbios son inseparables de la señal climática del ecosistema. Este estudio separa las influencias estacionales del clima de influencias causadas por alteraciones y decisiones de manejo, haciendo el análisis de series de tiempo interanual más consistente y interpretable. Comparamos el rendimiento actual del ecosistema (AEP) de cinco tipos de vegetación de pastizales del las tierras altas de Owyhee por nueve años con su rendimiento esperado del ecosistema (EEP). Datos de Índice Diferencial de Vegetación Normalizado de temporada de crecimiento integrado para cada una de las nueve temporadas de crecimiento sirvieron como una aproximación del AEP anual. Modelos de árbol de regresión usaron conjuntos de datos de potencial del sitio a largo plazo, clima estacional y cobertura del suelo para generar EEP anual, una estimación del desempeño del ecosistema que incorporando variaciones anuales del clima. La diferencia entre AEP y EEP proporcionó una medida de desempeño para cada píxel en el área de estudio. Anomalías de desempeño del ecosistema ocurrieron cuando el ecosistema se desempeño significativamente mejor o peor de lo que el modelo predijo. Cerca del $14 \%$ de las tierras altas de Owyhee mostraron una tendencia de bajo desempeño o alto desempeño $(P<0.10)$. Administradores de tierras pueden usar los resultados de modelos de desempeño del ecosistema de pastizal basados en clima para que ayude a soportar estrategias de manejo adaptivo.

Key Words: Artemisia tridentata, ecological model, Great Basin, NDVI, sagebrush steppe, site potential

\section{INTRODUCTION}

Monitoring rangeland ecosystem dynamics, production, and performance is valuable for researchers and land managers trying to understand, manage, and restore rangeland ecosystems, especially when faced with a changing global climate that

\footnotetext{
Research was funded by the Bureau of Land Management, USGS Climate Effects Network, Global Climate Change Research and Development, and USGS Land Remote Sensing. Work was performed under USGS contract G10PC00044 (Boyte).

Any use of trade, product, or form names is for descriptive purposes only and does not imply endorsement by the US Government.

Correspondence: Bruce K. Wylie, USGS EROS Center, Sioux Falls, SD 57198, USA. Email: wylie@usgs.gov

Manuscript received 30 March 2011; manuscript accepted 16 January 2012.
}

presents new threats to ecosystem stability. Remote sensing applications, geospatial analyses, and spatial modeling efforts can collectively assist in guiding restoration efforts of Great Basin ecosystems (Fleishman et al. 2009); however, ecosystem performance studies that use these technologies and procedures may prove to be difficult to interpret and put into an appropriate context if management decisions and disturbances that affect these ecosystems are inseparable from the ecosystem's climate signal (Archer 2004; Evans and Geerken 2004; Wylie et al. 2008). This is especially true in semiarid and arid environments that experience high interannual variability in precipitation. The analysis in this study used remote sensing archive data, geophysical and biophysical data, and regressiontree modeling techniques to separate seasonal weather influences from those of disturbances and management, making 
interannual time-series analysis (trends and persistence) of ecosystem performance more consistent and interpretable.

The arid and semiarid parts of the western United States are especially vulnerable to ecosystem threats; the Great Basin is described as one of the most endangered ecoregions in the United States (Pellant et al. 2004; Chambers and Wisdom 2009). Threats include a changed climate, increased human populations and water demands, non-native species invasion, reduced biological diversity, and increased fire frequency, size, and severity (Pellant et al. 2004; Chambers and Wisdom 2009). As early as the late 1800 s, evidence linked overgrazing to soil erosion and steep declines in forage production in the Great Basin (Pellant et al. 2004). Non-native annual grass invasions, most commonly cheatgrass (Bromus tectorum L.), increased fine fuel amounts that, in turn, increased fire spread rates, causing fire return intervals to be greatly reduced (Whisenant 1990; Link et al. 2006). The ensuing grass-fire cycle created a feedback where, in places, cheatgrass, with its exceptional seed-producing and reproductive characteristics, outcompeted native species and became the dominant land cover. This cheatgrass dominance results in shorter fire return intervals and larger, more contiguous fires within many rangeland communities.

Big sagebrush (Artemisia tridentata Nutt.) is an important land cover in the Owyhee Uplands. Prevéy et al. (2010) found that in the sagebrush steppe environment of southern Idaho, big sagebrush served as a foundation species that helped exclude exotic plants and enhance the presence of native forbs. Big sagebrush also provided integral habitat necessary for greater sage grouse (Centrocercus urophasianus) survival, a bird species that experienced declining reproductive numbers because of contracting big sagebrush extents (Hockett 2002; Connelly et al. 2003). Estimates showed this land cover contracted about $50 \%$ in the West since pre-settlement, and more contraction is likely in the near future (Dusek et al. 2002; Suring et al. 2005). The ability to monitor the performance of big sagebrush, as well as other rangeland vegetation types, may help develop adaptive management strategies for the Owyhee Uplands. Land managers engaged in developing adaptive management strategies need modeled and predictive results that account for interannual variations in weather that can help inform planning and restoration plans at local and regional scales. These models must remain flexible and relatively easy to adapt to changing conditions.

The primary objective of this study was to develop annual ecosystem performance models and associated maps for 2000 to 2008 at 250-m resolution for selected rangeland associations in the Owyhee Uplands, identifying areas where the expected ecosystem performance (EEP) was significantly different than the actual ecosystem performance (AEP), defined as ecosystem performance anomalies (EPAs). Secondary objectives included using the ecosystem performance time-series data to develop 1) a performance trend map that shows the trend of each pixel through the study period and 2) a persistent anomaly map that identifies areas of consistent underperformance and overperformance.

\section{METHODS}

\section{Study Area}

The Owyhee Uplands are located in the northern part of the Great Basin, covering 4.1 million ha in parts of three states

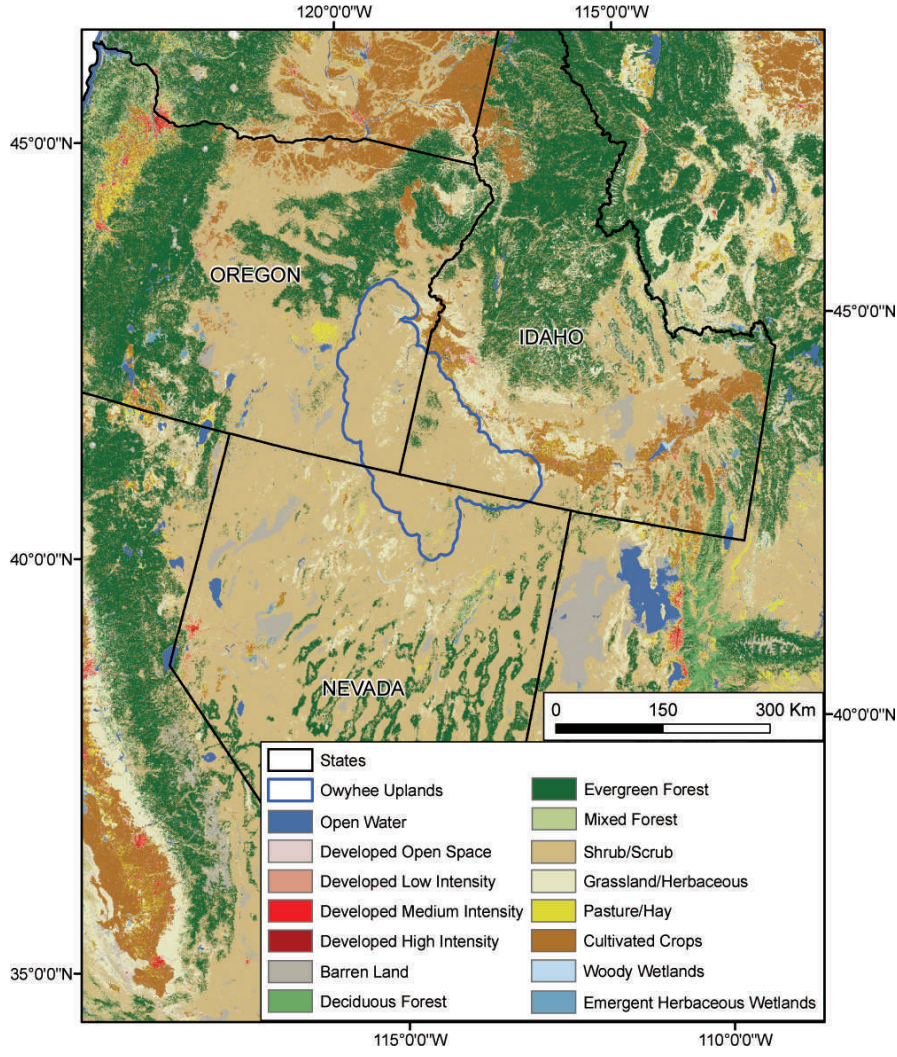

Figure 1. Owyhee Uplands boundary over 2001 National Land Cover Database.

including southwestern Idaho, northern Nevada, and southeastern Oregon (Fig. 1). Most of the area is managed by the US Bureau of Land Management (BLM). Predominant land cover consists of sagebrush shrub and grass, with sagebrush consisting of low sagebrush (Artemisia arbuscula Nutt.) and black sagebrush (A. nova A. Nelson) and a big sagebrush complex that includes Basin big sagebrush (A. tridentata Nutt. ssp. tridentata), Wyoming big sagebrush (A. tridentata Nutt. ssp. wyomingensis), and Mountain big sagebrush (A. tridentata Nutt. ssp. vaseyana). Bitterbrush (Purshia tridentata [Pursh] DC ) occupies a small area in the southern part of the landscape, and grass species include annual invasive grasses such as cheatgrass (Bromus tectorum L.) and native perennial grasses such as bluebunch wheatgrass (Pseudoroegneria spicata [Pursh] A. Löve), Sandberg bluegrass (Poa secunda J. Presl), and Idaho fescue (Festuca idahoensis Elmer). An evergreen forest is made up primarily of western juniper (Juniperus occidentalis Hook) (Vander Schaaf 1996; Shock 2011). Small areas of cultivated crop, other shrubs, and barren land make up the remainder of the land cover (Homer et al. 2004). The topography ranges from areas of little relief to mountainous terrain and steep canyons in the north, east central, and southern sections. The Owyhee Uplands receive modest precipitation amounts (200 to $400 \mathrm{~mm}$ annually), experience high evapotranspiration, host several waterways including the Owyhee and Bruneau Rivers, serve as a center for recreational activities, include dry land and irrigated agriculture, and provide grazing for livestock (USDA Forest Service 2010). 


\section{Step 1}

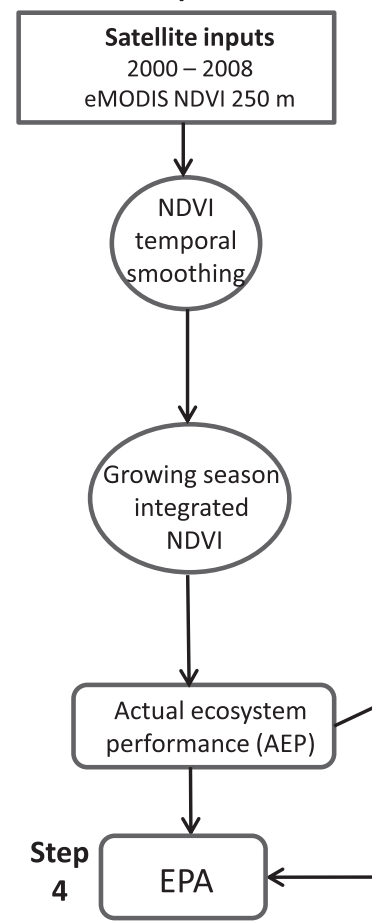

Step 3

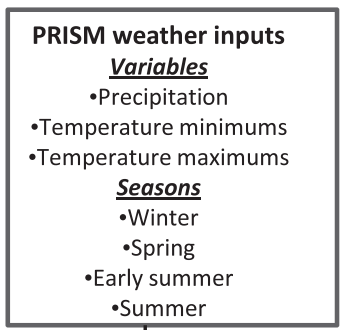

Step 2

$$
\begin{gathered}
\text { Site potential site-specific inputs } \\
\text { •Weather averages }(1971-2000) \\
\text {-Precipitation } \\
\text {-Temperature minimum } \\
\text {-Temperature maximum } \\
\text { •Elevation } \\
\text {-Aspect/slope } \\
\text { •NRCS SSURGO } \\
\text {-2001 National Land Cover Database } \\
\text { - Compound topographic index } \\
\text { • LANDFIRE site potential } \\
\text { • Major Land Resource Area } \\
\text { - Long-term growing season NDVI }
\end{gathered}
$$

Figure 2. Data inputs and the processes used to create the AEP, EEP, and EPA datasets. Adapted from Gu et al. (2011).

\section{Vegetation Class Development}

The rangeland classes focused on in this study were the big sagebrush complex, a general classification of low sagebrush from the Natural Resources Conservation Service's (NRCS) Soil Survey Geographic database (SSURGO) ecological site information, bitterbrush from SSURGO ecological site information, grass derived from the 2001 National Land Cover Database (NLCD), and a catch-all "other rangeland vegetation" class that refers generally to shrubs not classified with the big sagebrush complex, bitterbrush, or low sagebrush. Grass, as a general land cover class, was identified as dominant in certain parts of the Owyhee Uplands because grazing, range interventions (spraying, seeding, chaining, etc.), and fire disturbances have altered the historically sagebrush steppe environment so that now grass dominates an expanding portion of the landscape. The SSURGO ecological site data set was not available for about one-third of the study area. To remedy this spatial gap in the central part of the study area and to mitigate county and state boundaries evident in the SSURGO coverage, a boosted decision tree (RuleQuest Research 2008b; De'ath and Fabricius 2000; DeFries and Chan 2000) estimated the selected ecological site vegetation from temporally static variables. We generated 13252 random points in ERDAS Imagine 9.3 to train the model, and the model had an accuracy of $82 \%$. The variables used to estimate land cover classes were the following:

1) 1971 to 2000 PRISM climate data (PRISM Climate Group, Oregon State University ${ }^{1}$ ). A total of 12 climate variables were used including average precipitation and average temperature minimums/maximums partitioned into four seasonal periods and defined as winter (November-February),

${ }^{1}$ http://www. prismclimate.org spring (March-April), early summer (May-June), and summer (July).

2) Elevation data (calculated from 30-m DEMs).

3) Slope and aspect to identify steep slopes $(>8.5 \%)$ and south and north facing aspects (south $=$ between $135^{\circ}$ and $225^{\circ}$; north $=$ between $315^{\circ}$ and $45^{\circ}$ [where north equals $0^{\circ}$ ]).

4) A compound topographic index that serves as a wetness index and is a function of both slope and upstream contributing area (Beven and Kirkby 1979; Chaplot and Walter 2003).

\section{Ecosystem Performance Anomaly Development}

Remote sensing technologies can help identify and quantify vegetation greenness during a growing season, providing valuable information on vegetation performance. The technique employed in this study enhances that information's value by separating the weather effects in an ecosystem from disturbance and management effects. This makes the analysis of ecosystem performance more informative because the vegetation performance variance that occurs because of annual weather changes is isolated, allowing the variance caused by disturbances and management to be more evident. The modeling approach used in this study was outlined in detail in Wylie et al. (2008). In this study, however, the computation of each pixel's EEP was calculated based on the removal of burn disturbances that occurred within $5 \mathrm{yr}$ before the modeled year as opposed to $25 \mathrm{yr}$ in Wylie et al. (2008). The Wylie et al. (2008) study occurred in a boreal forest, and we expected a potentially faster fire recovery in rangelands. Several steps of this modeling process used rule-based piecewise regression techniques to improve the precision of the modeling and to better understand the mechanisms that control the relationships 
between the independent and dependent variables. Piecewise regression models are "broken-stick" models that have been used to better understand discrete and nonlinear biological problems through time, helping identify causal relationship between independent and dependent variables (Toms and Lesperance 2003; Wylie et al. 2007). More details on this piecewise regression technique are available in Wylie et al. (2008).

We developed the annual ecosystem performance maps in the Owyhee Uplands in four main steps. First, we developed a proxy for AEP. Second, we modeled a site potential data set that served as long-term AEP. Third, we modeled the EEP. And, fourth, we used the difference between AEP and EEP to identify EPAs (Fig. 2). This modeling process used multiple data sets, and each data set is described below.

AEP Data. We define actual ecosystem performance as the integrated vegetation dynamics that occur during a growing season in a specific ecosystem (Tieszen 1997; Wylie 2008). Wylie et al. (2003) demonstrated that the Normalized Difference Vegetation Index (NDVI) correlates to $\mathrm{CO}_{2}$ fluxes in a sagebrush steppe environment, and Tucker et al. (1985) did the same with photosynthetically active vegetation. Therefore, we used the expedited Moderate Resolution Imaging Spectroradiometer (eMODIS) NDVI at 250-m resolution (Jenkerson et al. 2010) that had been temporally smoothed (Swets et al. 2000) to estimate AEP for the Owyhee Uplands. Additional error components would be induced by converting NDVI to estimates of biomass, leaf area index (LAI), fraction of photosynthetic active radiation (FPAR), gross primary production, or net primary production. For example, MODIS LAI accuracy is an RMSE of 0.5 LAI units for non-broadleaf forest land covers, FPAR RMSE is $0.12,{ }^{2}$ and MODIS biomass estimates for winter wheat had a RMSE of $65 \mathrm{~g} \cdot \mathrm{m}^{-2}$ (Bao et al. 2009). Many of these MODIS biophysical parameters are produced at $1 \mathrm{~km}$ and $500 \mathrm{~m}$ resolutions. We used an integrated growing season NDVI (GSN), which is produced relatively consistently through time and space, directly as a synoptic proxy for AEP (Wylie et al. 2008) at a resolution of $250 \mathrm{~m}$. We defined the growing season as April through July for each year, 2000 to 2008. The eMODIS data were mapped from swath data directly to a conterminous US Lambert Azimuthal projection. The eMODIS data are 7-d composites based on an algorithm that selected the best pixel for the composite period by filtering through input surface reflectance layers that flag clouds, snow cover, or low view angles. A baseline value of 0.10 that is associated with bare soil and dormant vegetation was subsequently subtracted from the eMODIS NDVI with the remainder summed for the time period defined above. The annual GSNs were aggregated into an all-year GSN and used as the dependent variable in the development of the site potential data set.

Site Potential Data. Site potential accounted for regional longterm spatial variation in ecosystem performance. Nine different data sets, including long-term GSN as the dependent variable, were used to create the site potential data set. Where necessary, coarse resolution data were resampled to $250-\mathrm{m}$ resolution using bilinear interpolation to match eMODIS NDVI data set

${ }^{2}$ http://landval.gsfc.nasa.gov/ProductStatus.php?ProductID=MOD15 geographic extents. The independent variable data sets used to create site potential are the four datasets described in Vegetation Class Development section and the following four datasets:

1) 2001 NLCD land cover. ${ }^{3}$

2) NRCS's SSURGO Database soils range productivity for a normal year ${ }^{4}$; and ecological site dominant species data sets used to determine land cover in the study area in conjunction with the 2001 National Land Cover Database land cover.

3) LANDFIRE environmental site potential type used as a categorical variable to provide further vegetation delineation. ${ }^{5}$

4) NRCS Major Land Resource Area, ${ }^{6}$ also used as a categorical variable to delineate vegetation types.

Site potential maps of the five vegetation classes in this sagebrush steppe study were developed by mapping long-term GSN from topographic data, soils data, SSURGO production for a normal year, land cover data, and climate data. Modeling of site potential was done to minimize potential effects on longterm GSN in rangelands that might have been degraded for a long time. Piecewise regression models (using Cubist software; RuleQuest Research 2008a) were derived from stratified random locations within each respective rangeland land cover type. The data points varied roughly with the respective areas of each of the rangeland land classes and ranged from 5385 for the big sagebrush complex to 384 for grass. A separate site potential model was developed for each of the vegetation class.

EEP Data. The creation of the EEP model included the following three data layers: 1) seasonally averaged weather from the PRISM Climate Group partitioned into identical seasonal periods as climate data, 2) land cover data sets LANDFIRE and NRCS Major Land Resource Area used for stratification purposes, and 3) results from the site potential model. This modeling approach allowed site potential to account for regional long-term variations in AEP associated with elevation and site environmental conditions, and seasonal weather to focus on interannual variations in productivity.

A rule-based, piecewise regression technique was used to develop the EEP models (Wylie et al. 2008). The EEP models used annual GSN from 2000 to 2008 as the dependent variables. We trained the model on a set of stratified (high, medium, low site potential) random locations within each target rangeland class to predict GSN from site potential, weather, and other information. The training databases for all five vegetation types comprised 15 independent variables including the seasonally integrated weather data from each year, 2000 to 2008, the LANDFIRE and Major Lands Resources Area (MLRA) data, and the respective site potential model for the particular modeled vegetation class. EEP data are used with the AEP data to generate the ecosystem performance anomaly data set.

\footnotetext{
${ }^{3}$ http://www.mrlc.gov

${ }^{4}$ http://soils.usda.gov/survey/geography/ssurgo

${ }^{5}$ http://www.landfire.gov

${ }^{6} \mathrm{http}: / /$ soils. usda.gov/survey/geography/mlra
} 


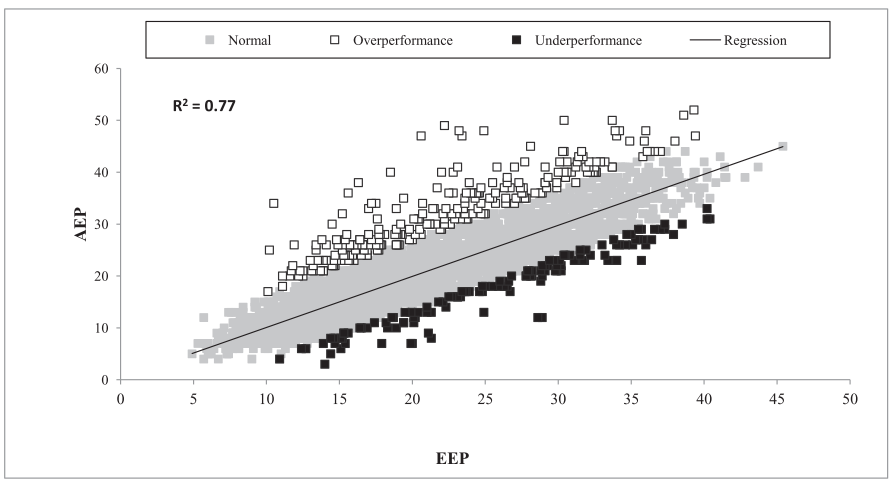

Figure 3. Actual ecosystem performance (AEP) regressed on expected ecosystem performance (EEP) showing the regression line and the $90 \%$ confidence limits used to determine significant model anomalies. Pixels unburned during the previous $5 \mathrm{yr}$ were randomly selected for each of the five vegetation types.

Ecosystem Performance Anomalies (EPAs). The influence of weather variability is captured with EEP. AEP captures variations associated with weather, disturbances, and management actions. The difference between these two variables, i.e., EPAs, isolates disturbance and management effects from weather. We separate these effects by incorporating weather variations into the modeling process and removing known disturbances like fire from EEP model development. Management and disturbance effects are averaged out or not accounted for when we model EEP, forcing management and disturbance effects into the EEP model error term and model residuals which are mapped as the EPA data sets.

In Figure 3, EEP is plotted against AEP for the big sagebrush vegetation class, and the vertical distances for respective points from the linear regression line represents the EPA. The unfilled squares above the regression line represent overperforming anomalies, black squares below the regression line represent underperforming anomalies, and the gray squares that occupy the spaces around the regression line represent normally performing pixels that occur within the model's $90 \%$ confidence intervals. While some performance anomalies' pixels are assumed to represent model error, the confidence interval should capture most of these pixels, and they should represent only a small part of the overall performance anomaly information. The $90 \%$ confidence intervals apply to the AEP regressed on the EEP regression line and not the 1:1 line. This means that the confidence interval thresholds for anomalous responses to weather do not apply to simple difference maps (AEP-EEP) but rather to the AEP difference from estimates of the regression (EEP*; AEP regressed on EEP), which accounts for minor EEP estimation biases. EPA is thus modified to be $\mathrm{EPA}=\mathrm{AEP}-\mathrm{EEP} *$, where $\mathrm{EEP}^{*}$ is the regression-estimated EEP. Annual anomaly maps were created using the difference between AEP and EEP* for each year.

\section{Validation}

We validated model data using three sources: 1) LANDFIRE vegetation composition data from LANDFIRE zones 9 and 18 that used extensive field-referenced data from multiple sources ranging from a 20-to-50-m transect (Connelly et al. 2003) to two 50-m transects, 2) the BLM's Jarbidge District Ecological
Site Inventory (ESI) vegetation composition and cover data recorded based on three $91-\mathrm{m}$ line intercept transects radiating from a center point, and 3) stocking rates that were obtained by the Idaho Department of Lands and the BLM for selected areas in and around the 2007 Murphy Complex Fire (Launchbaugh et al. 2008). The ESI and stocking rate data were limited geographically to the southeast portion of the Owyhee Uplands. The ESI data were gathered in 2006, and the stocking rate data were calculated for 2006 and 2007. Much of the southeast portion of the Owyhee Uplands burned as part of the Murphy Complex Fire from 16 July 2007 to 2 August 2007.

\section{RESULTS}

\section{Site Potential}

Table 1 shows the structure for each vegetation type's longterm site potential model, how often the models used the individual variables for stratification and prediction purposes, and their $R^{2}$ values. The training $R^{2}$ for the five models ranged from 0.64 to 0.83 , with the low sage model providing the best fit. $R^{2}$ values for the test data ranged from 0.62 to 0.81 , with the grass model providing the best fit. The other shrub category received the lowest $R^{2}$ values.

\section{Expected Ecosystem Performance}

The structure for each vegetation type's model, how often the models used the individual variables for stratification and prediction purposes, their $R^{2}$ values, and mean-squared errors are shown in Table 2. Each vegetation type's EEP model independent data sets were seasonal weather (precipitation, temperature minimums/maximums), land cover, and site potential. The dependent variable was the annual GSN. The training $R^{2}$ values for the five models ranged from 0.71 to 0.90 , with the grass model providing the best fit. $R^{2}$ values for the test data were similar to the training data, ranging from 0.71 to 0.88 , with the other shrub category receiving the lowest $R^{2}$ values at 0.71 for both the test and training data sets (Table 2). The training and test data were stratified by three land-coverspecific production levels and then randomly partitioned for each land cover type.

Site potential was the dominant driver in the development of all five vegetation models. The dominant climatic driver was seasonal precipitation (ppt) for all five vegetation types, with summer ppt and early summer ppt each being used twice. Land cover variables from MLRA and LANDFIRE were used to stratify the models, but they were not used in the predictive analysis (Table 2).

\section{Ecosystem Performance Anomalies}

EPA maps for five rangeland vegetation types for 2000 to 2008 are shown in Figure 4. Using the Monitoring Trends in Burn Severity (MTBS) data ${ }^{7}$ we determined that negative values for performance anomalies sometimes indicate areas that have burned recently. They may also represent areas that were intensively grazed that year (Launchbaugh et al. 2008). Areas that have not recently burned but still underperformed for three or more years are potential subjects for further investigation

${ }^{7}$ http://mtbs.gov 
Table 1. Driving variables for site potential showing model usage for stratification (boldface numerals) and prediction (lightface numerals) by land cover type. Dashes indicate variable not used.

\begin{tabular}{|c|c|c|c|c|c|c|c|c|c|c|}
\hline \multirow{3}{*}{ Driving variable } & \multicolumn{10}{|c|}{ Land cover } \\
\hline & \multicolumn{2}{|c|}{ Big sage } & \multicolumn{2}{|c|}{ Grass } & \multicolumn{2}{|c|}{ Low sage } & \multicolumn{2}{|c|}{ Other shrub } & \multicolumn{2}{|c|}{ Bitterbrush } \\
\hline & & & & & & & & & & \\
\hline SSURGO & 89 & 81 & 12 & 12 & 29 & 39 & 36 & 38 & 28 & 51 \\
\hline Precipitation & 89 & 83 & 84 & 75 & 98 & 84 & 56 & 80 & 27 & 89 \\
\hline Temp min & 85 & 80 & 100 & 91 & 64 & 96 & 52 & 80 & 44 & 75 \\
\hline Elevation & 61 & 91 & - & 49 & 48 & 99 & 64 & 90 & 79 & 67 \\
\hline Temp max & 37 & 91 & - & 91 & 6 & 78 & 77 & 89 & 57 & 89 \\
\hline North slope & 32 & 71 & - & - & - & 90 & 5 & 69 & - & 15 \\
\hline MLRA & 27 & - & - & - & - & - & 4 & - & - & - \\
\hline LANDFIRE & 21 & - & - & - & 32 & - & 53 & - & 41 & - \\
\hline CTI & - & 25 & - & 75 & - & 7 & - & 28 & - & 11 \\
\hline South slope & - & 24 & - & - & - & 91 & - & 38 & 30 & 35 \\
\hline Model structure & \multicolumn{2}{|c|}{40 rules, simple model } & \multicolumn{2}{|c|}{5 rules, simple model } & \multicolumn{2}{|c|}{12 rules, simple model } & \multicolumn{2}{|c|}{18 rules, committee of 5} & \multicolumn{2}{|c|}{12 rules, committee of 3} \\
\hline Train $R^{2}$ & \multicolumn{2}{|c|}{0.72} & \multicolumn{2}{|c|}{0.77} & \multicolumn{2}{|c|}{0.83} & \multicolumn{2}{|c|}{0.64} & \multicolumn{2}{|c|}{0.77} \\
\hline Test $R^{2}$ & \multicolumn{2}{|c|}{0.64} & \multicolumn{2}{|c|}{0.81} & \multicolumn{2}{|c|}{0.74} & \multicolumn{2}{|c|}{0.62} & \multicolumn{2}{|c|}{0.62} \\
\hline
\end{tabular}

because they could be areas where the level of grazing activity exceeds the land's capacity to regenerate itself under that time period's environmental conditions. Figure 5 shows the 2008 performance anomaly map for a portion of the southeast section of the Owyhee Uplands that experienced wildfire in 2007. The modeled performance anomaly responded as expected with large areas of underperforming and low normal performing pixels dominating the area. Many areas near the perimeter of the fire boundary that did not underperform are areas where the MTBS categorized the severity of the fire as unburned to low. Most areas of overperforming pixels shown on the map are located outside of the burn area except in a northeastern portion of the fire, where fire intensities were lower and the vegetation, dominated by Idaho fescue, recovered quickly after the fire.

\section{Validation}

Bare soil field data were obtained from the LANDFIRE pooled collaborative database (2003) and BLM ESI data (2006). Site potential values for each of five vegetation types were

Table 2. Driving variables for EEP showing model usage for stratification (boldface numerals) and prediction (lightface numerals) by land cover types. Dashes indicate variable not used.

\begin{tabular}{|c|c|c|c|c|c|c|c|c|c|c|}
\hline & \multicolumn{10}{|c|}{ Land cover } \\
\hline & \multicolumn{2}{|c|}{ Big sage } & \multicolumn{2}{|c|}{ Grass } & \multicolumn{2}{|c|}{ Low sage } & \multicolumn{2}{|c|}{ Other shrub } & \multicolumn{2}{|c|}{ Bitterbrush } \\
\hline \multicolumn{11}{|l|}{ Driving variable } \\
\hline Early summer precipitation (ppt) & 75 & 71 & 27 & 80 & 54 & 77 & 69 & 60 & 47 & 71 \\
\hline Site potential & 73 & 98 & 71 & 89 & 96 & 96 & 60 & 98 & 68 & 95 \\
\hline Spring ppt & 64 & 70 & 28 & 82 & 38 & 72 & 16 & 75 & 30 & 77 \\
\hline Winter temp maximum $\left(t_{\max }\right)$ & 54 & 70 & 6 & 47 & 26 & 55 & 4 & 54 & 3 & 55 \\
\hline Winter ppt & 43 & 61 & 69 & 74 & 26 & 60 & 32 & 63 & 11 & 56 \\
\hline LANDFIRE & 39 & - & 22 & - & 17 & - & 38 & - & 24 & - \\
\hline Winter temp minimum $\left(t_{\min }\right)$ & 32 & 57 & 1 & 37 & 9 & 51 & 28 & 67 & - & 76 \\
\hline Summer ppt & 31 & 52 & 24 & 71 & 5 & 64 & 46 & 57 & 47 & 73 \\
\hline Spring $t_{\max }$ & 28 & 60 & 18 & 77 & 27 & 59 & 24 & 69 & 25 & 67 \\
\hline Early summer $t_{\min }$ & 28 & 54 & - & 66 & 21 & 62 & 26 & 67 & 6 & 62 \\
\hline Early summer $t_{\max }$ & 20 & 61 & 13 & 74 & 32 & 67 & 33 & 66 & 37 & 85 \\
\hline Summer $t_{\min }$ & 19 & 56 & 13 & 60 & 5 & 57 & 19 & 62 & 7 & 39 \\
\hline Spring $t_{\min }$ & 17 & 60 & 26 & 38 & 12 & 64 & 25 & 71 & 14 & 69 \\
\hline Summer $t_{\max }$ & 13 & 60 & - & 40 & 6 & 59 & 6 & 58 & 14 & 73 \\
\hline MLRA & 5 & - & - & - & 4 & - & 2 & - & - & - \\
\hline Model structure & \multicolumn{2}{|c|}{100 rules, committee of 3} & \multicolumn{2}{|c|}{7 rules, committee of 3} & \multicolumn{2}{|c|}{31 rules, committee of 3} & \multicolumn{2}{|c|}{108 rules, committee of 5} & 20 rules, & ittee of 5 \\
\hline Train $R^{2}$ & \multicolumn{2}{|c|}{0.83} & \multicolumn{2}{|c|}{0.9} & \multicolumn{2}{|c|}{0.81} & \multicolumn{2}{|c|}{0.79} & \multicolumn{2}{|c|}{0.71} \\
\hline Test $R^{2}$ & \multicolumn{2}{|c|}{0.81} & \multicolumn{2}{|c|}{0.88} & \multicolumn{2}{|c|}{0.76} & \multicolumn{2}{|c|}{0.74} & \multicolumn{2}{|c|}{0.71} \\
\hline Training MSE & \multicolumn{2}{|c|}{15.93} & \multicolumn{2}{|c|}{7.85} & \multicolumn{2}{|c|}{10.99} & \multicolumn{2}{|c|}{12.67} & \multicolumn{2}{|c|}{14.43} \\
\hline
\end{tabular}



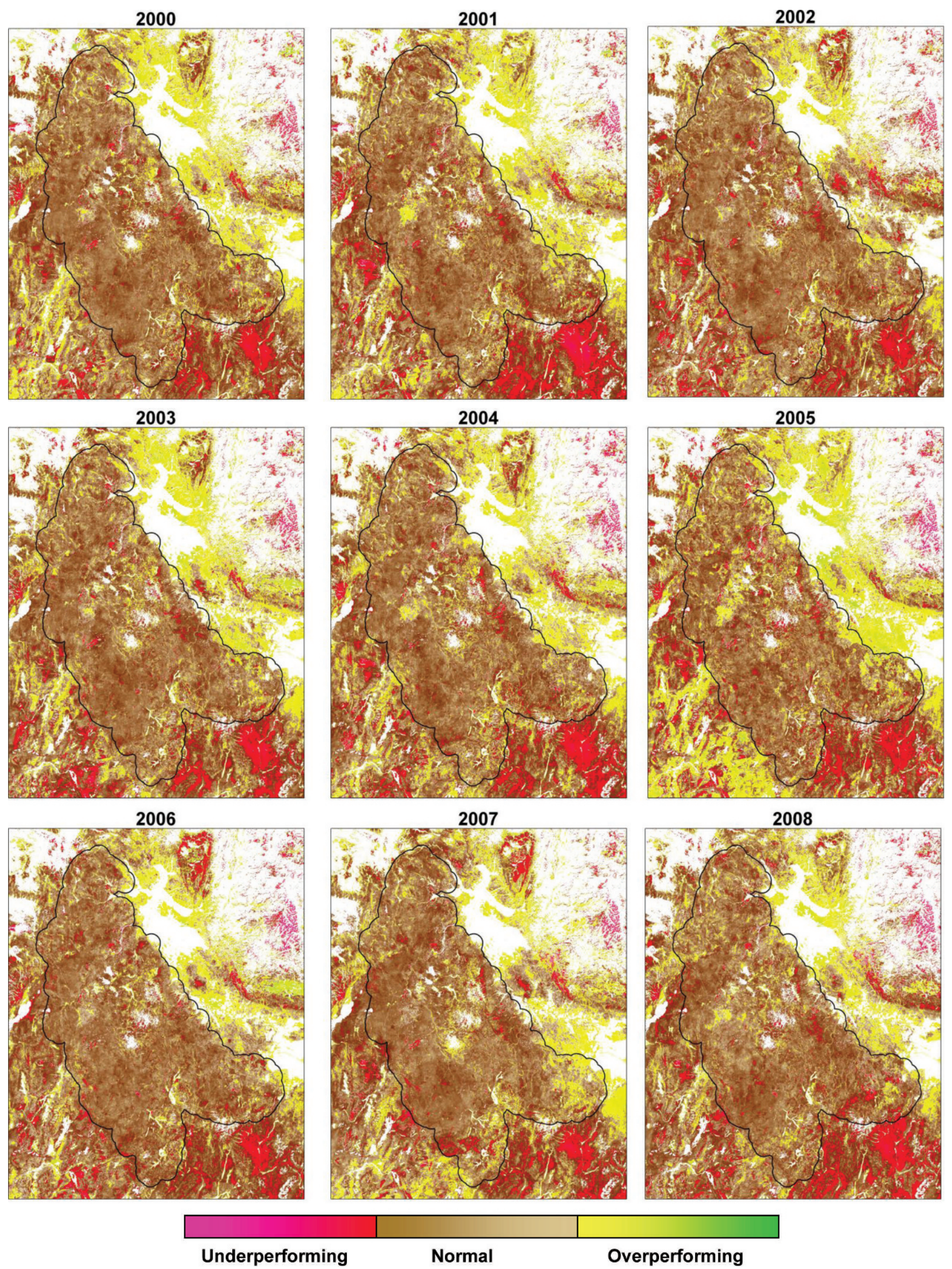

Figure 4. Rangeland ecosystem performance for five vegetation types in the Owyhee Uplands, 2000-2008. Areas colored magenta to red represent underperforming pixels (lower actual production than expected given the weather and site potential), areas colored dark brown to tan represent normal performing pixels (within the error range of the EEP model), and areas colored yellow to green represent overperforming pixels (more productive than expected given the weather and site potential). Training data were selected from the study area, so areas outside the study area should be interpreted with caution. 


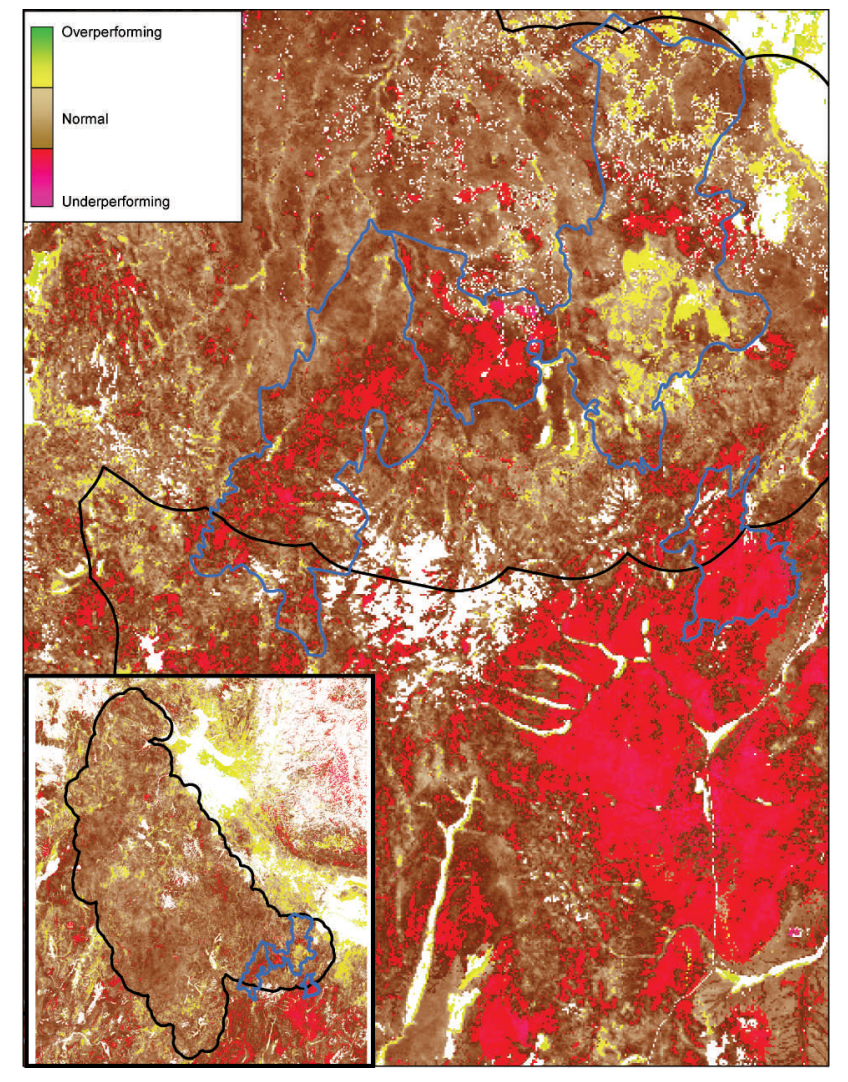

Figure 5. The 2008 performance anomaly map of the five vegetation types in the southeast Owyhee Uplands with large areas that underperformed in response to the Murphy Complex Fires.

compared to the percent of bare soil. The spatial resolution of the field plots ranged from 183 to $30 \mathrm{~m}^{2}$. Pastures that had multiple year overperforming anomalies the year of and two years prior to the plot data collection may have experienced lower stocking rates, or could have been rested one or both years. Other disturbances, like fire, were also used to explain some mean anomaly values that were lower than what pasture usage would indicate.

Percent bare soil is often used as a relative indicator of range condition (de Soyza et al. 2000; Gadzia and Graham 2009). Figure 6 shows a log-linear relationship between the percent of bare soil from the field plots and site potential modeled for normal performing areas in this study for big sagebrush, other shrub, and low sage land covers. The determination of the performance anomaly for a data point, i.e., normal, over, or under, was based on the modeled ecosystem performance from 2000 to 2008. Given the spatial resolution differences between MODIS and the field plots, and that the field data came from multiple years, the general relationships with normal performing pixels corroborated the site potential maps. There was a general log-linear consistency across both the LANDFIRE and ESI data, but with ESI data generally having lower percentages of bare soil and higher site potential than LANDFIRE data. The few field plots with underperforming EPAs were ESI plots, and all were plotted above the regression line. The further above the regression line the underperforming field sites were indicates higher certainty in a greater-than-expected percent bare soil and a lower range condition.
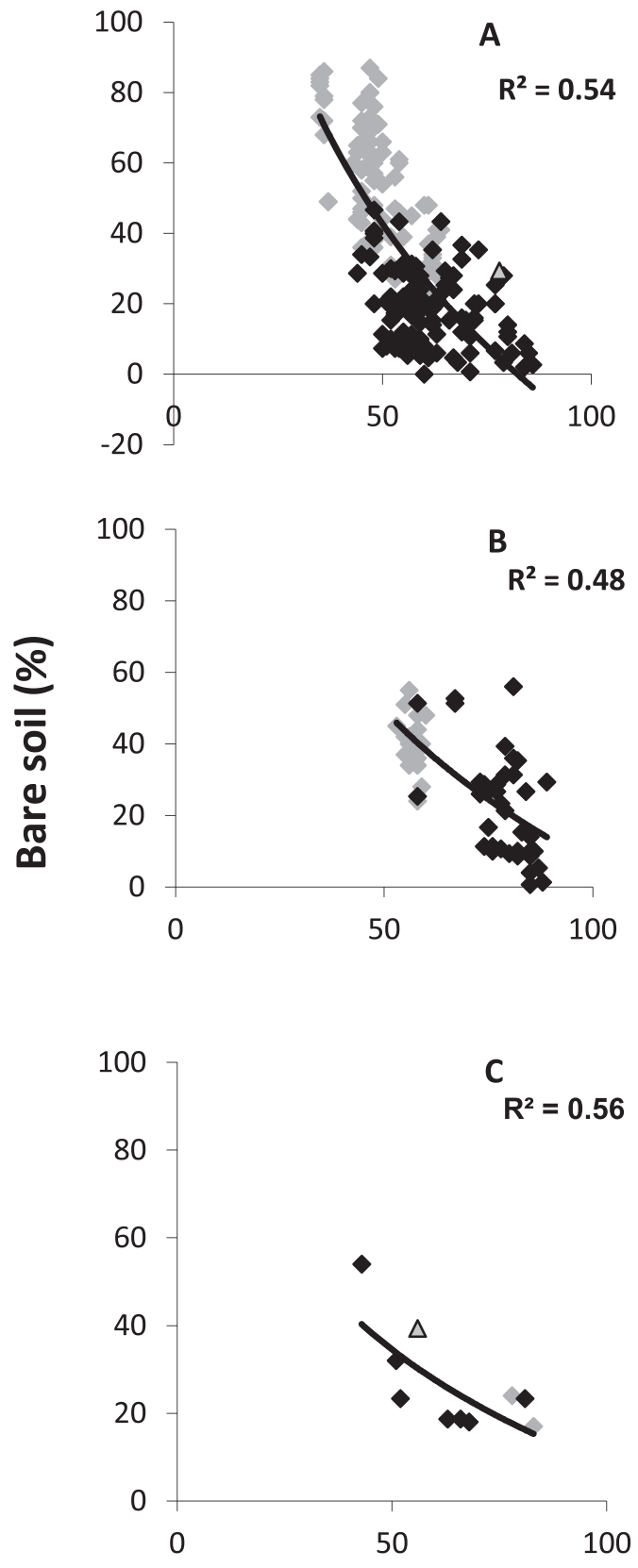

Site potential

Figure 6. Validation of Big Sagebrush (A), Other Shrub (B), and Low Sage (C) site potentials in the Owyhee Uplands using 2003 LANDFIRE and $2006 \mathrm{ESI}$ data. LANDFIRE normal performance points are gray diamonds, ESI normal performance points are black, and ESI underperformance points are triangles.

Figure 7 shows the relationship between 2006 stocking rates and the difference between the 2006 and 2007 modeled ecosystem performance that corresponds to those pastures. The figure also shows the relationship between 2007 stocking rates and the difference between the 2007 and 2008 modeled ecosystem performance for those same pastures. We constrained this analysis to pastures where land cover equaled $75 \%$ grass or greater because grass productivity is more tightly linked to grazing than are perennial shrub systems. The 


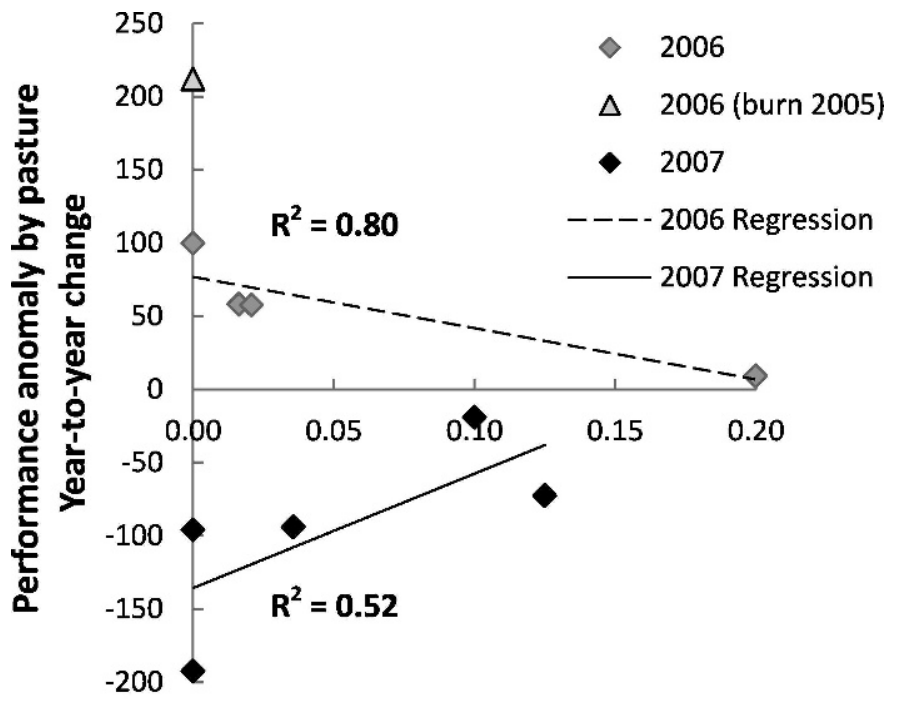

Animal Unit Month $\cdot$ Acre $^{-1}$

Figure 7. Validation of the southeast Owyhee Uplands grass performance anomalies using 2006 and 2007 stocking rate data. The $x$ axis represents animal unit monthly acre, and the $y$ axis represents the difference between the performance anomaly for 2006 and 2007 (2006 regression) and 2007 and 2008 (2007 regression). All pastures burned in the 2007 Murphy Complex Fire.

modeled ecosystem performance values for individual pastures were derived from an average of the pixels within the specific pasture.

The comparison of 2006 stocking rates to change in ecosystem performance from 2006 to 2007 displays how our ecosystem performance analysis can show that grazing intensity affects pasture performance during the next growing season. During 2007, each of the five pastures displayed below the $x$ axis in Figure 7 burned, at least partially, in the Murphy Complex Fire; consequently, the comparison of 2007 stocking rates to change in ecosystem performance from 2007 to 2008 demonstrates how our ecosystem performance analysis can show how a fire disturbance affects pasture performance during the next growing season. Based on a limited sample size, a strong negative linear relationship exists and indicates the less intense the grazing, the greater the increase in ecosystem performance between the 2006 and 2007 ecosystem performance. (One pasture burned during 2005 and was not grazed in 2006 , so that pasture was removed from the regression calculation.) A modest positive relationship exists between grazing intensity and performance and indicates the more intense the grazing the smaller the fire-related reduction between the 2007 and 2008 ecosystem performance.

In an analysis of grazing intensity and ecosystem performance for 30 pastures, regardless of land cover dominance, we found 17 pastures that experienced a decrease in grazing intensity between 2006 and 2007 also experienced an increase in ecosystem performance for the same time period. One pasture experienced an increase in grazing intensity and a decrease in ecosystem performance. Four pastures were rested during both 2006 and 2007, three because they burned in 2005 . The three pastures that burned all experienced an increase in ecosystem performance from 2006 to 2007 . The pasture that

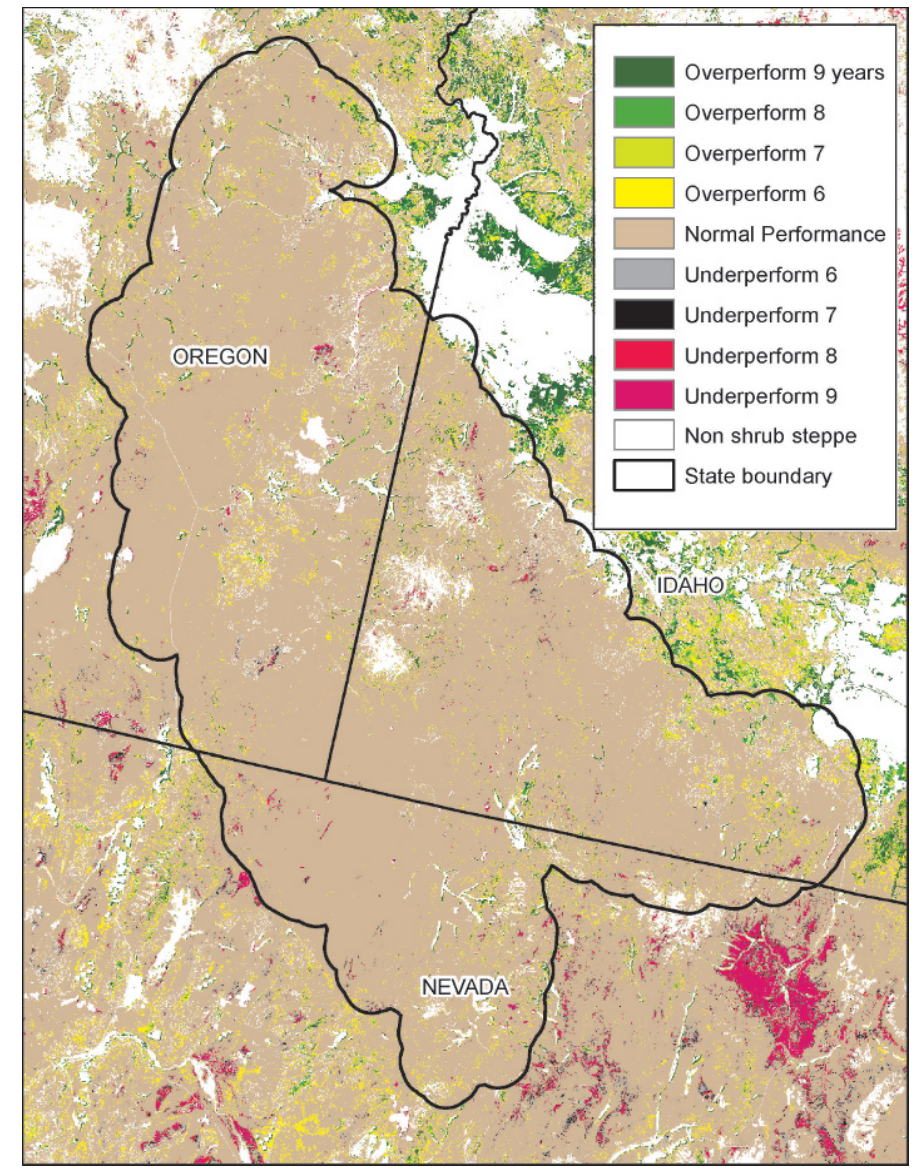

Figure 8. Persistent anomaly map with areas that underperformed for at least 6 of $9 \mathrm{yr}$, overperformed for at least 6 of $9 \mathrm{yr}$, or with patterns shown as normal performance. Training data were selected from the study area, so areas outside the study area should be interpreted with caution.

was rested both years but did not experience fire in 2005 saw a slight decline in its ecosystem performance. We saw an increase in grazing intensity and an increase in ecosystem performance in eight pastures. Analysis of ecosystem performances compared to changes in grazing intensity showed that overall 21 $(70 \%)$ of the pastures met our expectations, i.e., an inverse relationship existed between a pasture's ecosystem performance and grazing intensity from the previous 1-2 yr. In cases where ecosystem performances did not respond to grazing intensity as expected, pasture performance could be related to the timing and amount of grazing and precipitation. With light to moderate grazing and adequate moisture, tillering can stimulate vegetation growth, and grazing in our study area was generally light.

\section{Ecosystem Performance: Persistent Anomalies and Trends}

Figure 8 highlights the persistent underperforming and overperforming areas over the 9-yr study period. The majority of the persistently underperforming areas occurred outside of the Owyhee Uplands. The land cover extents were developed within the Owyhee boundary and SSURGO extents were clipped to the boundary, so the EPA maps are less reliable outside the Owyhee Uplands. Also, the Owyhee Uplands may 


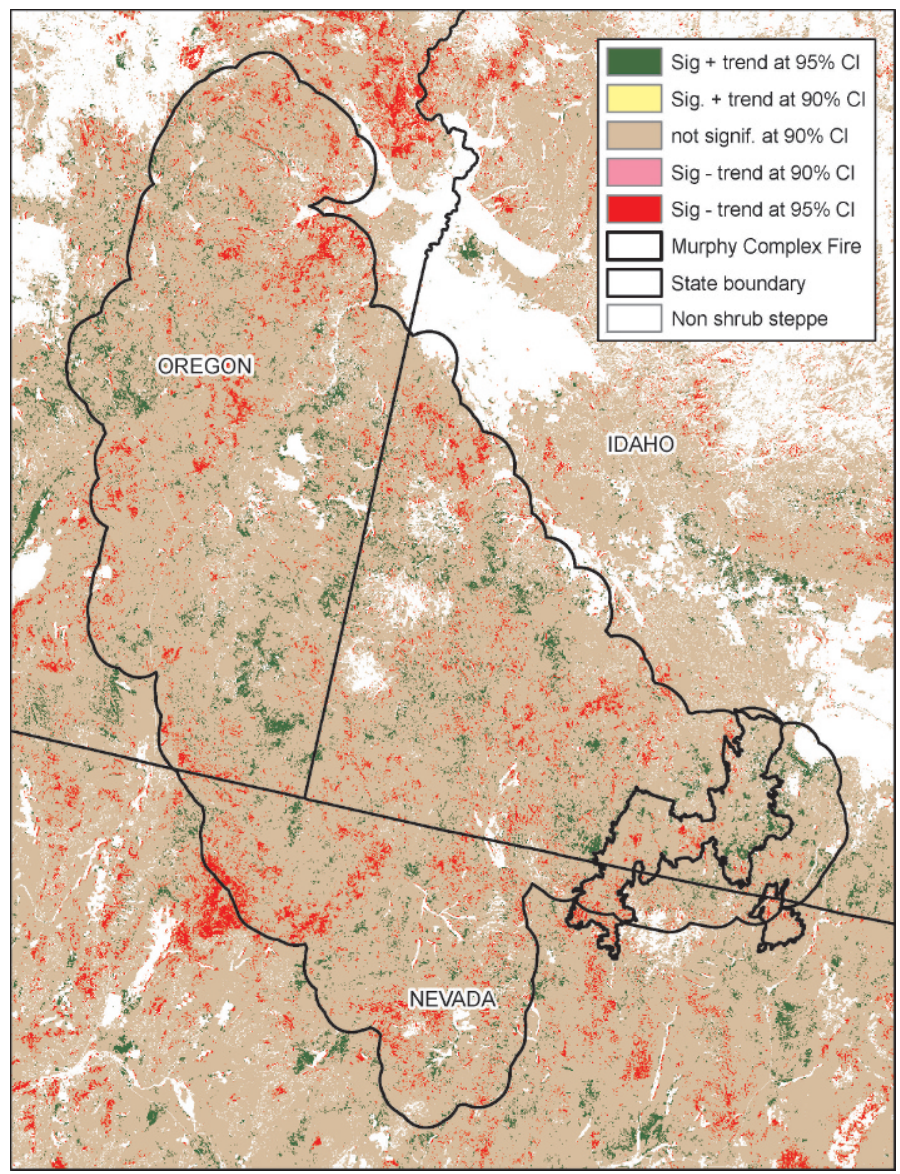

Figure 9. Trend map with the significance value of the slope coefficient of EPA regressed on years for each pixel. Training data were selected from the study area, so areas outside the study area should be interpreted with caution.

be in a more stable condition than surrounding areas. Figure 9 shows the linear trend (slope of EPA versus year) of each pixel in the study area. Approximately $86 \%$ of the area within the Owyhee Uplands boundary did not show a significant trend $(P<0.10)$, and more land area had a negative $(8 \%)$ than a positive $(5 \%)$ trend. The largest areas with a negative trend were also distributed outside of the Owyhee Uplands area, where less reliable AEP models were expected, although there is a portion in the northern area inside the Uplands boundary with a significant negative trend. Fire disturbances account for some of these negative trends found within the Uplands boundary. Significant positive trending areas in the Uplands are scattered throughout, but large patches exist in the northwest, central, and southeast areas. Only a very small portion of overperforming trend areas had experienced fire since 2005. Cheatgrass, an annual exotic grass, is a very successful postfire invader in portions of this region, but did not make up a significant percentage of land cover in areas that burned from 2005 to 2007. Overall, little land cover (1.4\%) consisted of $70 \%$ or more cheatgrass; $18 \%$ of the land cover consisted of more than $30 \%$ cheatgrass (Peterson 2007). Most of the performance trends in these areas were not significant at the $90 \%$ confidence level.

\section{DISCUSSION}

To validate our findings, we established that there was a general productivity relationship between normal performing pixels and bare soil and between performance anomaly scores and stocking rates. The relationship between modeled site potential and percentage of bare soil from LANDFIRE and ESI datasets was relatively modest (Fig. 6). However, considering the variations in LANDFIRE and ESI field plot sizes and the difference in these plot sizes from the site potential 250-m data, this confirms that site potential captured variations in longterm site productivity. The relationship between stocking rate data and the performance anomaly scores (Fig. 7) was negative and strong in 2006 when the analysis was limited to unburned pastures dominated by grass. The relationship was positive and relatively modest in 2007 when the same pastures in the dataset were all burned in the Murphy Complex Fire. Launchbaugh et al. (2008) observed variations of burn severity at fence lines that separated pastures with different grazing regimes in the area burned by the Murphy Complex Fire and then used the BEHAVE Plus modeling system to simulate how current year and residual fuel loads would affect fire behavior in sagebrush steppe and grassland ecosystems under various conditions. They determined that, under some environmental conditions, when grazing reduced fuel loads, less extreme burn severities could occur.

While different species respond to environmental conditions differently, and there can be value in separating the various

Table 3. The ecosystem performance anomalies mean values for the nine largest 2006 fires within the Owyhee Uplands and their mean values and differences for subsequent years.

\begin{tabular}{|c|c|c|c|c|c|c|}
\hline Fire name & Ignition date & 2006 EPA & 2007 EPA & $\begin{array}{c}2006 \text { to } 2007 \\
\text { difference }\end{array}$ & 2008 EPA & $\begin{array}{l}2007 \text { to } 2008 \\
\text { difference }\end{array}$ \\
\hline Jackie's Butte & 3 September & 57 & 11 & -46 & 108 & 97 \\
\hline Jerry Wells & 28 July & 1 & -14 & -15 & 85 & 99 \\
\hline Old Wind & 30 September & -25 & 102 & 127 & 93 & -9 \\
\hline Taylor & 27 July & 14 & -46 & -60 & 34 & 80 \\
\hline Snow Canyon & 20 August & 21 & -76 & -97 & 25 & 101 \\
\hline Happy Valley & 22 July & 22 & -14 & -36 & -8 & 6 \\
\hline Star Mountain & 21 August & -35 & -45 & -10 & 28 & 73 \\
\hline Chubby Spain & 21 August & 20 & -32 & -52 & 38 & 70 \\
\hline Winters & 25 July & -21 & -46 & -25 & 13 & 59 \\
\hline
\end{tabular}


responses of these species, the approach we employed does not attempt to partition the relative contribution of shrubs, forbs, and grasses but rather quantifies if vegetation is responding to environmental conditions in a similar fashion as other vegetation in its rangeland type. However, if one of our objectives had been to explore how different species respond to disturbance, we could have run multiple land cover predictions for every pixel before and after a disturbance. We then could assess if a pixel's response to weather changed after a disturbance, and if it did so, we could postulate that the disturbance changed the land cover.

Unburned pastures that underperformed could have been heavily grazed early in the growing season or even during years prior to the growing season when underperformance occurred. We found for pastures in 2006, 70\% showed increased ecosystem performance when grazing intensity decreased or decreased ecosystem performance when grazing intensity increased. Holechek et al. (1999) reported that across a variety of range types, including sagebrush steppe, forage production was an average of $23 \%$ and $36 \%$ higher in moderately and lightly grazed pastures, respectively, than in heavily grazed pastures, where heavily grazed is defined "as a degree of herbage utilization that does not permit desirable forage species to maintain themselves." If a pasture was rested for a period of time, or if grazing was light or moderate, the expectation was that vegetation recovery occurred and that the pasture's performance would improve in subsequent years (Holechek et al. 1999). Our stocking rate validation chart (Fig. 7) showed that the two pastures with greater than $75 \%$ grass that were rested in 2006 showed significantly improved performance in 2007 when compared to 2006 , especially the pasture that burned in 2005. This conforms to postfire ecosystem-expected responses in the big sagebrush ecosystem with grass recovery occurring in about $1 \mathrm{yr}$ and grass height returning to normal in about 2 yr (Beck et al. 2009). Postfire effects within the Owyhee Uplands showed that the EPA values declined in the year after a fire occurred. A decline in EPA values is expected the first year after a fire with EPA increases expected to begin during the second year. For example, in areas where the nine largest fires occurred within the Owyhee Uplands boundary during 2006, mean EPA values decreased in 2007. The 2008 EPA values, however, increased from the 2007 values (Table 3), except for the Old Wind fire, which was rated by MTBS as $82 \%$ unburned to low severity. The ignition date for every fire occurred at the tail end of, or after, the growing season period (1 April to 31 July) used to develop our GSN. The fires would, if at all, minimally affect 2006 EPA values.

\section{MANAGEMENT IMPLICATIONS}

The Great Basin ecosystem is in a constant state of change, and the ability to monitor that ecosystem change by separating weather effects from disturbances and management activities can prove valuable to land managers. Therefore, the ecosystem performance modeling technique presented in this paper represents a promising contribution to rangeland management. Our study demonstrated the capability to reliably separate climatic influence from past management actions (grazing) and natural disturbances (fire). Ecosystem performance models can reliably characterize spatiotemporal conditions and associated trends in vegetation production across broad regions. Areas that show significant departure in a negative direction from normal vegetation responses to weather and site conditions for a specific year, or, that show a consistent departure in a negative direction from normal vegetation responses to weather and site conditions, are spatially identifiable. These areas can be prioritized for field visits and validation and possibly additional management actions as they could help identify sites of decreased functional resiliency or areas approaching a critical ecological threshold.

Using this technique, we demonstrated that AEP models can successfully characterize relative estimates of total annual production and associated annual trends in sagebrush ecosystems. As a result, ecosystem performance monitoring using remote sensing, geospatial analyses, and modeling technologies is a valuable tool for examining the influence of climate change on future rangeland community distribution. Projecting future productivity of rangeland ecosystems under alternative climate scenarios could inform land managers on potential ecosystem trends and support associated adaptive management strategies.

\section{ACKNOWLEDGMENTS}

We wish to thank Norman Bliss for providing the NRCS's SSURGO soil data used for range productivity and land cover vegetation type and Claudia Young for translating the abstract from English to Spanish. The authors also thank Jennifer Rover, Norman Bliss, and two anonymous reviewers whose comments improved this manuscript.

\section{LITERATURE CITED}

ArCheR, E. 2004. Beyond the "climate versus grazing" impasse: using remote sensing to investigate the effects of grazing system choice on vegetation cover in the eastern Karoo. Journal of Arid Environments 57:381-408.

BAO, Y., W. GAO, AND Z. GAO. 2009. Estimation of winter wheat biomass based on remote sensing data at various spatial and spectral resolutions. Frontiers in Earth Science in China 3:118-128.

Beck, J. L., J. Connelly, and K. P. Reese. 2009. Recovery of greater sage-grouse habitat features in Wyoming big sagebrush following prescribed fire. Restoration Ecology 17:393-403.

BEVEn, K. J., AND M. J. KIRKBY. 1979. A physically based, variable contributing area model of basin hydrology. Hydrological Sciences Bulletin 24:43-69.

Chambers, J. C., AND M. J. Wisdom. 2009. Priority research and management issues for the imperiled Great Basin of the western United States. Restoration Ecology 17:707-714.

Chaplot, V., and C. Walter. 2003. Subsurface topography to enhance the prediction of the spatial distribution of soil wetness. Hydrologic Processes 17:2567-2580.

Connelly, J. W., K. P. Reese, and M. A. Schroeder. 2003. Monitoring of greater sagegrouse habitats and populations. Moscow, ID, USA: College of Natural Resources Experiment Station, University of Idaho. State Bulletin 80. 47 p.

DE'ATH, G., AND K. E. Fabricius. 2000. Classification and regression trees: a powerful yet simple technique for ecological data analysis. Ecology 81:3178-3192.

DeFries, R. S., and J. Cheung-Wal Chan. 2000. Multiple criteria for evaluating machine learning algorithms for land cover classification from satellite data. Remote Sensing of Environment 74:503-515.

de Soyza, A. G., J. W. Van Zee, W. G. Whitford, A. Neale, N. Tallent-Hallsel, J. E. HerRick, and K. M. Havstad. 2000. Indicators of Great Basin rangeland health. Journal of Arid Environments 45:289-304. 
Dusek, G. L., C. D. Eustace, and J. G. Peterson. 2002. The ecology and status of sage grouse in Montana. Intermountain Journal of Sciences 8:67-81.

Evans, J., and R. Geerken. 2004. Discrimination between climate and humaninduced dryland degradation. Journal of Arid Environments 57:535-554.

Fleishman, E., J. C. Chambers, and M. J. Wisdom. 2009. Introduction to the special section on alternative futures for Great Basin ecosystems. Restoration Ecology 17:704-706.

GadzIA, K., AND T. Graham. 2009. Bullseye: targeting your rangeland health objectives. Available at: http://www.rmsgadzia.com/PDFs/Bulleseye.pdf. Accessed 30 December 2011.

Gu, Y., S. P. Boyte, B. K. Wylie, And L. L. Tieszen. 2012. Identifying grasslands suitable for cellulosic feedstock crops in the Greater Platte River Basin: dynamic modeling of ecosystem performance with $250 \mathrm{~m}$ eMODIS. Global Change Biology: Bioenergy 4:96-106.

Hockett, G. A. 2002. Livestock impacts on herbaceous components of Sage Grouse habitat: a review. Intermountain Journal of Sciences 8:105-114.

Holechek, J. L., H. Gomez, F. Molinar, and D. Galt. 1999. Grazing studies: what we've learned. Rangelands 21(2):12-16.

Homer, C., C. Huang, L. Yang, B. Wylie, and M. Coan. 2004. Development of a 2001 national landcover database for the United States. Photogrammetric Engineering and Remote Sensing 70:829-840.

Jenkerson, C. B., T. Maiersperger, and G. Schmidt. 2010. eMODIS: a user-friendly data source. Resont, VA, USA: US Geological Survey. US Geological Survey Open-File Report 2010-1055. 10 p.

Launchbaugh, K., B. Brammer, M. L. Brooks, S. Bunting, P. Clark, J. Davison, M. Fleming, R. Kay, M. Pellant, D. A. Pyke, and B. K. Wylie. 2008. Interactions among livestock grazing, vegetation type, and fire behavior in the Murphy Wildland Fire Complex in Idaho and Nevada, July 2007. Reston, VA, USA: US Geological Survey. US Geological Survey Open-File Report 2008-1214. 42 p.

Link, S. O., C. W. Keeler, R. W. Hill, and E. Hagen. 2006. Bromus tectorum cover mapping and fire risk. International Journal of Wildland Fire 15:113-119.

Pellant, M., B. Abbey, and S. Karl. 2004. Restoring the Great Basin desert, USA: integrating science, management, and people. Environmental Monitoring and Assessment 99:169-179.

Peterson, E. B. 2007. A map of annual grasses in the Owyhee Uplands, spring 2006, derived from Multitemporal Landsat 5 TM Imagery. Report for the USDI Bureau of Land Management, Nevada State Office, Reno. Carson City, NV, USA: Nevada Natural Heritage Program. $24 p$.

Prevéy, J. S., M. J. Germino, N. J. Huntly, and R. S. Inouye. 2010. Exotic plants increase and native plants decrease with loss of foundation species in sagebrush steppe. Plant Ecology 207:39-51.

RuleQuest Research. 2008a. Cubist. Version 2.05. St. Ives, NSW, Australia: RuleQuest Pty Ltd.

RuleQuest Research. 2008b. See5/C5.0. Version 2.05. St. Ives, NSW, Australia: RuleQuest Pty Ltd.
Sноск, M. P. 2011. Environmental contest of the Owyhee uplands. Available at: http://www.cropinfo.net/Locallinks/OwyheeUplands.htm. Accessed 25 July 2011.

Suring, L. H., M. J. Wisdom, R. J. Tausch, R. F. Miller, M. M. Rowland, L. Schueck, AND C. W. MenIKE. 2005. Modeling threats to sagebrush and other shrubland communities. In: M. J. Wisdom, M. M. Rowland, and L. H. Suring [EDs.]. Habitat threats in the sagebrush ecosystem: methods of regional assessment and applications in the Great Basin. Lawrence, KS, USA: Alliance Communications Group, Allen Press. p. 114-149.

Swets, D. L., B. C. Reed, J. D. Rowland, and S. E. Marko. 2000. A weighted leastsquares approach to temporal NDVI smoothing. In: Proceedings of the 1999 ASPRS Annual Conference, From Image to Information; 17-21 May 1999; Portland, OR, USA. Bethesda, MD, USA: American Society for Photogrammetry and Remote Sensing. CD-ROM.

Tieszen, L. L., B. C. Reed, N. B. Bliss, B. K. Wylie, and D. D. Jong. 1997. NDVI, C 3 and $C^{4}$ production, and distributions in Great Plains grassland land cover classes. Ecological Applications 7:59-78.

Toms, J. D., And M. L. LesperanCE. 2003. Piecewise regression: a tool for identifying ecological thresholds. Ecology 84:2034-2041.

Tucker, C. J., J. R. G. Townshend, and T. E. Goff. 1985. African land-cover classification using satellite data. Science 227:369-375.

USDA Forest Service. 2012. Chapter 48: ecological subregions of the United States: intermountain semi-desert. http://www.fs.fed.us/land/pubs/ecoregions/ch48.html. Accessed 28 April 2010.

Vander SchaAF, D. 1996. A report on the Owyhee Uplands ecoregion: Oregon, Idaho, Nevada. Portland, OR, USA: US Bureau of Land Management and The Nature Conservancy. $43 \mathrm{p}$.

Whisenant, S. G. 1990. Changing fire frequencies on Idaho's Snake River plains: ecological and management implication. In: E. D. McArthur, E. M. Romney, S. D. Smith, and P. T. Tueller [EDs.]. Symposium on cheatgrass invasion, shrub die-off, and other aspects of shrub biology and management; Las Vegas, NV, USA. Ogden, UT, USA: USDA. USDA General Technical Report INT276. p. 4-10.

Wylie, B. K., E. A. Fosnight, T. G. Gillmanov, A. B. Frank, J. A. Morgan, M. R. Haferkamp, and T. P. Meyers. 2007. Adaptive data-driven models for estimating carbon fluxes in the Northern Great Plains. Remote Sensing of Environment 106:399-413.

Wylie, B. K., D. A. Johnson, E. Laca, N. Z. Saliendra, T. Gilmanov, B. C. Reed, L. L. Tieszen, AND B. B. Worstell. 2003. Calibration of remotely sensed coarse resolution NDVI to $\mathrm{CO}_{2}$ fluxes in a sagebrush steppe ecosystem. Remote Sensing of Environment 85:243-255.

Wylie, B. K., L. Zhang, N. Bliss, L. Jı, L. L. Tieszen, and W. M. Jolly. 2008. Integrating modelling and remote sensing to identify ecosystem performance anomalies in the boreal forest, Yukon River Basin, Alaska. International Journal of Digital Earth 1:196-220. 